\title{
Parathyroid hormone assay: problems and opportunities
}

\author{
Kevin J. Martin • Esther A. González
}

Received: 16 March 2007 /Revised: 9 April 2007 / Accepted: 11 April 2007 / Published online: 22 May 2007

(C) IPNA 2007

\begin{abstract}
The assay of parathyroid hormone continues to remain problematic as a result of the presence in the circulation of a variety of parathyroid hormone (PTH) peptides derived from secretion and from peripheral metabolism. The detection of these PTH fragments to varying degrees leads to widely differing results in the various assays used, particularly in the setting of chronic kidney disease, where PTH fragments accumulate as glomerular filtration rate (GFR) falls. The differing results not only lead to problems in comparing values from various laboratories but also limit efforts to develop useful clinical practice guidelines. At the same time, research into the precise identification of the PTH fragments which contribute to the assay problems has uncovered a relatively new area of parathyroid research that has pointed to potential biologic activity of PTH peptides previously thought to be biologically inactive and which may act on a novel PTH receptor. These issues have brought new focus to the difficulties in standardization of PTH assays and have provoked efforts to provide standards to help in the characterization of PTH assays and to facilitate the development of clinical practice guidelines.
\end{abstract}

Keywords Parathyroid hormone $\cdot$ PTH $\cdot$ Assay $\cdot$ Renal osteodystrophy . Chronic kidney disease

Assay of parathyroid hormone is extremely important in clinical medicine because of the major role of parathyroid hormone in the regulation of mineral metabolism and skeletal physiology. Since the introduction of radioimmu-

K. J. Martin $(\bowtie) \cdot$ E. A. González

Division of Nephrology, Saint Louis University,

3635 Vista Avenue,

St. Louis, MO 63110, USA

e-mail: martinkj@slu.edu noassay for parathyroid hormone (PTH) in 1963 by Berson et al., the assay of parathyroid hormone has been problematic and remains so to the present day [1]. The initial assays used polyclonal antisera, raised against intact parathyroid hormone, an 84 amino-acid peptide, which had been purified from parathyroid glands. Assay specificity varied considerably with different antisera and gave rise to terms such as N-terminal assays, midregion assays, and Cterminal PTH assays, according to the predominant specificity of the antisera used. While all of these assays had some clinical utility, they also allowed the characterization of the secretion and metabolism of PTH which revealed the basis for the widely different results that were obtained with different assays [2]. Thus, it was demonstrated that circulating immunoreactive parathyroid hormone was a mixture of the intact 84 amino-acid hormone peptide and several smaller molecular weight peptide fragments that were derived by secretion from the parathyroid gland as well as generated by peripheral metabolism of PTH [3-6]. The PTH peptides reacted in various assays to various degrees. Thus, the assay of parathyroid hormone was not only complicated by the reaction of these various PTH fragments in the particular assay used, but was also complicated by the fact that many of these fragments depended upon the kidney for their removal from the circulation and, accordingly, accumulated to a high degree in the setting of kidney disease [7]. While structurefunction studies of parathyroid hormone indicated that the structural determinants for biologic activity resided within the first 34 amino acids, assays directed towards this region of PTH proved to be of limited value in clinical situations. Paradoxically, it appeared that radioimmunoassays with determinants towards the middle and C-terminal region of the PTH molecule appeared to provide the best clinical utility [2]. 
A major breakthrough in PTH assay occurred with the application of immunometric assay technology to the measurement of PTH $[8,9]$. With these PTH assays, PTH was captured from serum using an antibody directed towards one region of the PTH molecule (usually towards the C-terminal region) and then detected with an antibody directed towards the other end of the PTH molecule (usually within the Nterminal 34 amino acids). Such two-site assays were believed to measure intact PTH (thus, were called "intact" PTH assays) and became widely utilized clinically and are the main type of PTH assay used at the present time. Detailed investigation over the past several years has revealed, however, that such assays are not specific for intact PTH but also detect a family of PTH peptides that are truncated at the N-terminus, a major one of which is PTH (784) $[10,11]$, as illustrated in Fig. 1. These findings not only brought a new area of confusion to the field of parathyroid hormone assay but also sparked further research, which has revealed interesting and important findings.

Further refinements in assay technique, by utilizing detection antibodies that had specificity for the first four amino-acids of PTH, allowed the measurement of true PTH (1-84) and facilitated detailed investigations of parathyroid hormone assay and parathyroid hormone physiology [12]. Although such specific PTH (1-84) assays are not in widespread clinical use today, they provided a tool for detailed research on parathyroid physiology and parathyroid hormone assay. These findings led to a reinvestigation for potential biologic activity in PTH fragments that were truncated at the N-terminus of the PTH (1-84) molecule. By the use of synthetic human PTH (7-84), it was demonstrated that some biological activity could be attributed to such PTH fragments that differed in direction from that of intact PTH (1-84) [13, 14]. Thus, while intact parathyroid hormone administration elevated serum calcium, N-terminally truncated PTH fragments such as human PTH 7-84, administered to rats, appeared to lower serum calcium, and when co-administered with human PTH (1-84), blunted the calcemic response. Those observations brought new credence to the work of Murray and others from many years before, which had originally suggested that some biologic activity might be attributable to fragments of parathyroid hormone [15].

These observations have expanded our knowledge of parathyroid physiology, but, at the same time, they have focused attention on some significant clinical problems. One such problem is that even with current immunometric assay techniques, there is considerable heterogeneity in results obtained using different assays from different manufacturers [16]. The widely different results obtained likely stems from the variable recognition of PTH fragments such as PTH (7-84) by the various assays used. An additional problem which follows is the questions that surround the development and application of practice guidelines for appropriate therapeutic targets for the desirable levels of parathyroid hormone with regard to the control of hyperparathyroidism in the setting of chronic kidney disease. Thus, a pressing clinical issue is how to compare results from one laboratory with those of another, with regard to the development of practice guidelines.

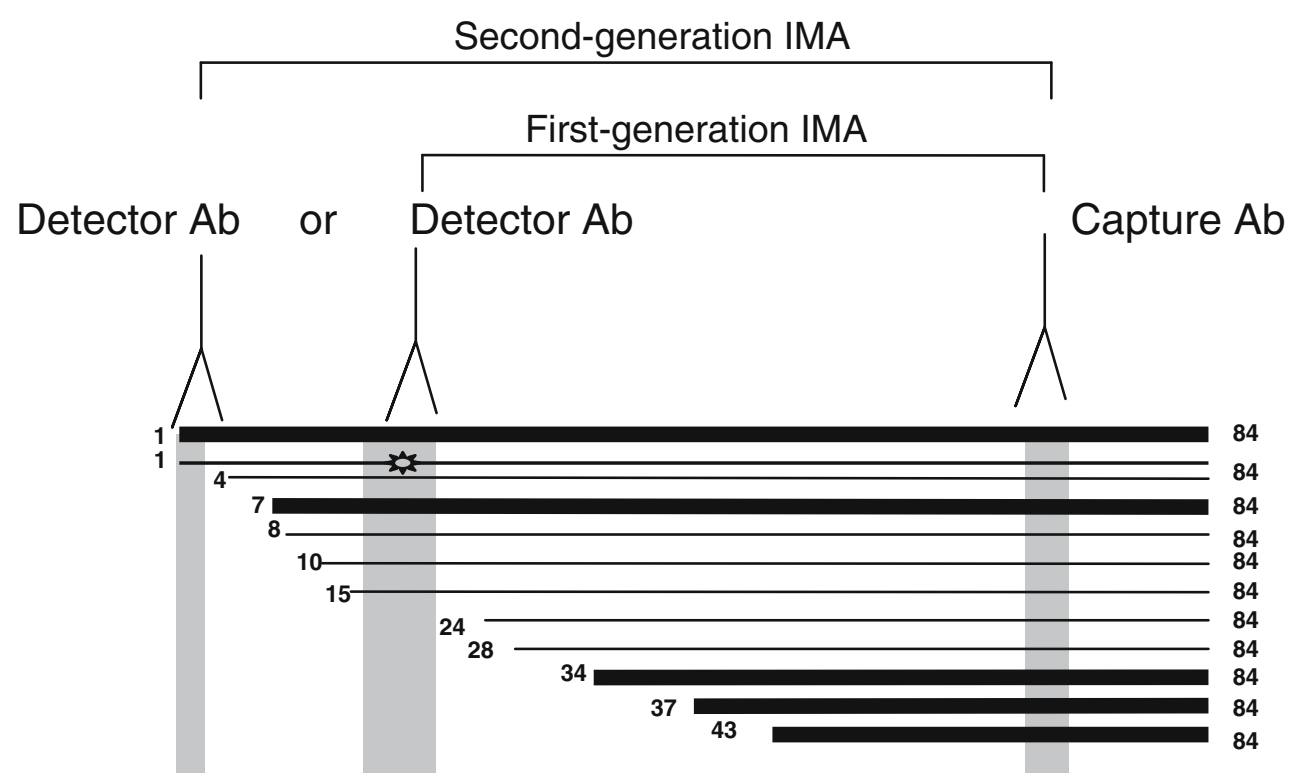

Fig. 1 Diagram of the multiple species of PTH peptides in the circulation. The major forms are depicted by heavy lines. The gray areas depict the regions of the PTH sequence that are detected by various antibodies for first-generation and second-generation immu- nometric assays and indicate the PTH peptides that would be detected in each assay. The symbol (2) depicts a PTH 1-84 peptide that is likely post-translationally modified in a region that interferes with its detection by first-generation immunometric assays 
On the other hand, these apparent problems in PTH assay also lead to a number of opportunities that may help the field move forward. First, the recognition of potential biologic activity for N-terminally truncated PTH fragments provides a stimulus to try and uncover and define the physiological importance of the biological role for such PTH fragments in humans. Some evidence in vitro and in animal experiments has been developed to indicate the likely presence of a specific receptor for such PTH fragments (C-PTH-R), and preliminary data have suggested that such receptors might exist particularly in cells of the osteocyte lineage, thereby opening a new field of parathyroid biology [17-19]. These observations also provide the opportunity to learn how such PTH fragments might function in a milieu where many types of PTH fragments exist and circulate, such as in chronic kidney disease, and, thus, the opportunity exists to learn whether these PTH fragments will have a spectrum of activities when they exist alone or in combination. The C-PTH-R differs from the PTH receptor (PTH-R1), which is responsible for the classical actions of PTH. PTH fragments with a truncated N-terminus, such as PTH 7-84, do not bind to the PTH-R1 [20].

An additional problem raised by these observations is the difficulty in trying to standardize PTH assay results from different laboratories or reagent suppliers using the various techniques and to achieve precise characterization of antisera used. This issue is not unique to the assay of PTH but is also relevant to other peptide hormone assays, such as the assay of growth hormone [21]. The provision of accurate PTH standards that could be used worldwide would be helpful in this regard. Similarly, interpretation of results obtained at the present time might also be facilitated by the provision of biological samples on a worldwide basis that could aid in the general characterization of assays used and help with clinical decision making, particularly in the setting of chronic kidney disease. These observations also provide the stimulus and opportunity to revisit the use of parathyroid hormone assay as a bone marker for the management of renal osteodystrophy, and will likely lead to a new era of bone biopsy to define correlations of parathyroid hormone values and other biomarkers in the current therapeutic era to try and facilitate clinical management. To this point in time, intact PTH measurements have been a relatively imprecise predictor of bone turnover [2224]. It has also been suggested that measurement of Nterminally truncated PTH fragments such as PTH (7-84), together with the values for PTH (1-84), might provide useful information $[25,26]$. This is an extremely controversial area that requires much additional work to define the biological role for PTH (7-84) in humans in a complex milieu of other PTH fragments and to understand the factors that may alter the relative amounts of PTH and fragments, before clinical decision making should be based upon such measurements [27-32].
In summary, problems with the assay of parathyroid hormone continue but have uncovered new areas of parathyroid hormone physiology and opened a new area of investigation into potential biologic activity of PTH fragments. As these assay problems are solved, and efforts at standardization of PTH assays continue, it is likely that we will be able to understand the total spectrum of biologic activity of PTH and PTH fragments and incorporate the information into clinical practice to improve the assessment and management of abnormalities of mineral metabolism in a variety of clinical circumstances.

\section{References}

1. Berson SA, Yalow RS, Aurbach GD, Potts JT Jr (1963) Immunoassay of bovine and human parathyroid hormone. Proc Natl Acad Sci USA 49:613-617

2. Martin KJ, Hruska K, Freitag JJ, Bellorin-Font E, Klahr S, Slatopolsky E (1980) Clinical utility of radioimmunoassays for parathyroid hormone. Miner Electrolyte Metab 3:283-290

3. Hanley DA, Takatsuki K, Sultan JM, Schneider AB, Sherwood LM (1978) Direct release of parathyroid hormone fragments from functioning bovine parathyroid glands in vitro. J Clin Invest 62:1247-1254

4. Martin KJ, Hruska KA, Freitag JJ, Klahr S, Slatopolsky E (1979) The peripheral metabolism of parathyroid hormone. N Engl J Med 301:1092-1098

5. Mayer GP, Keaton JA, Hurst JG, Habener JF (1979) Effects of plasma calcium concentration on the relative proportion of hormone and carboxyl fragments in parathyroid venous blood. Endocrinology 104:1778-1784

6. Segre BV, D'Amour P, Potts JT (1976) Metabolism of radioiodinated bovine parathyroid hormone in the rat. Endocrinology 99:1645-1652

7. Martin KJ, Hruska KA, Lewis J, Anderson C, Slatopolsky E (1977) The renal handling of parathyroid hormone. Role of peritubular uptake and glomerular filtration. J Clin Invest 60:808-814

8. Brown RC, Aston JP, Weeks I, Woodhead JS (1987) Circulating intact parathyroid hormone measured by a two-site immunochemiluminometric assay. J Clin Endocrinol Metab 65:407-414

9. Nussbaum SR, Zahradnik RJ, Lavigne JR, Brennan GL, NozawaUng K, Kim LY, Keutmann HT, Wang CA, Potts JT Jr, Segre GV (1987) Highly sensitive two-site immunoradiometric assay of parathyrin, and its clinical utility in evaluating patients with hypercalcemia. Clin Chem 33:1364-1367

10. D'Amour P, Brossard JH, Rousseau L, Nguyen-Yamamoto L, Nassif E, Lazure C, Gauthier D, Lavigne JR, Zahradnik RJ (2005) Structure of non-(1-84) PTH fragments secreted by parathyroid glands in primary and secondary hyperparathyroidism. Kidney Int 68:998-1007

11. Lepage R, Roy L, Brossard JH, Rousseau L, Dorais C, Lazure C, D'Amour P (1998) A non-(1-84) circulating parathyroid hormone (PTH) fragment interferes significantly with intact PTH commercial assay measurements in uremic samples. Clin Chem 44:805-809

12. Gao P, Scheibel S, D'Amour P, John MR, Rao SD, Schmidt-Gayk H, Cantor TL (2001) Development of a novel immunoradiometric assay exclusively for biologically active whole parathyroid hormone 1-84: implications for improvement of accurate assessment of parathyroid function. J Bone Miner Res 16:605-614 
13. Nguyen-Yamamoto L, Rousseau L, Brossard JH, Lepage R, D'Amour P (2001) Synthetic carboxyl-terminal fragments of parathyroid hormone (PTH) decrease ionized calcium concentration in rats by acting on a receptor different from the PTH/PTHrelated peptide receptor. Endocrinology 142:1386-1392

14. Slatopolsky E, Finch J, Clay P, Martin D, Sicard G, Singer G, Gao P, Cantor T, Dusso A (2000) A novel mechanism for skeletal resistance in uremia. Kidney Int 58:753-761

15. Murray TM, Rao LG, Divieti P, Bringhurst FR (2005) Parathyroid hormone secretion and action: evidence for discrete receptors for the carboxyl-terminal region and related biological actions of carboxyl- terminal ligands. Endocr Rev 26:78-113

16. Souberbielle JC, Boutten A, Carlier MC, Chevenne D, Coumaros G, Lawson-Body E, Massart C, Monge M, Myara J, Parent X, Plouvier E, Houillier P (2006) Inter-method variability in PTH measurement: implication for the care of CKD patients. Kidney Int 70:345-350

17. Divieti P, Inomata N, Chapin K, Singh R, Juppner H, Bringhurst FR (2001) Receptors for the carboxyl-terminal region of $\mathrm{PTH}(1-84)$ are highly expressed in osteocytic cells. Endocrinology 142:916-925

18. Divieti P, John MR, Juppner H, Bringhurst FR (2002) Human PTH(7-84) inhibits bone resorption in vitro via actions independent of the type $1 \mathrm{PTH} / \mathrm{PTHrP}$ receptor. Endocrinology 143:171-176

19. Langub MC, Monier-Faugere MC, Wang G, Williams JP, Koszewski NJ, Malluche HH (2003) Administration of PTH-(7$84)$ antagonizes the effects of PTH-(1-84) on bone in rats with moderate renal failure. Endocrinology 144:1135-1138

20. Martin KJ, Gonzalez EA (2001) The evolution of assays for parathyroid hormone. Curr Opin Nephrol Hypertens 10:569-574

21. Hauffa BP, Lehmann N, Bettendorf M, Mehls O, Dorr HG, Partsch CJ, Schwarz HP, Stahnke N, Steinkamp H, Said E, Sander S, Ranke MB, German KIGS/IGLU Study Group (2004) Central reassessment of $\mathrm{GH}$ concentrations measured at local treatment centers in children with impaired growth: consequences for patient management. Eur J Endocrinol 150:291-297

22. Goodman WG, Ramirez JA, Belin TR, Chon Y, Gales B, Segre GV, Salusky IB (1994) Development of adynamic bone in patients with secondary hyperparathyroidism after intermittent calcitriol therapy. Kidney Int 46:1160-1166
23. Qi Q, Monier-Faugere MC, Geng Z, Malluche HH (1995) Predictive value of serum parathyroid hormone levels for bone turnover in patients on chronic maintenance dialysis. Am J Kidney Dis 26:622-631

24. Salusky IB, Kuizon BD, Belin TR, Ramirez JA, Gales B, Segre GV, Goodman WG (1998) Intermittent calcitriol therapy in secondary hyperparathyroidism: a comparison between oral and intraperitoneal administration. Kidney Int 54:907-914

25. Monier-Faugere MC, Geng Z, Mawad H, Friedler RM, Gao P, Cantor TL, Malluche HH (2001) Improved assessment of bone turnover by the PTH-(1-84)/large C-PTH fragments ratio in ESRD patients. Kidney Int 60:1460-1468

26. Waller SC, Ridout D, Cantor T, Rees L (2005) Parathyroid hormone and growth in children with chronic renal failure. Kidney Int 67:2338-2345

27. Coen G, Bonucci E, Ballanti P, Balducci A, Calabria S, Nicolai GA, Fischer MS, Lifrieri F, Manni M, Morosetti M, Moscaritolo E, Sardella D (2002) PTH 1-84 and PTH "7-84" in the noninvasive diagnosis of renal bone disease. Am J Kidney Dis 40:348-354

28. Godber IM, Parker CR, Lawson N, Hitch T, Porter CJ, Roe SD, Cassidy MJ, Hosking DJ (2002) Comparison of intact and 'whole molecule' parathyroid hormone assays in patients with histologically confirmed post-renal transplant osteodystrophy. Ann Clin Biochem 39:314-317

29. Goodman WG, Juppner H, Salusky IB, Sherrard DJ (2003) Parathyroid hormone (PTH), PTH-derived peptides, and new PTH assays in renal osteodystrophy. Kidney Int 63:1-11

30. Nakanishi S, Kazama JJ, Shigematsu T, Iwasaki Y, Cantor TL, Kurosawa T, Fukagawa M (2001) Comparison of intact PTH assay and whole PTH assay in long-term dialysis patients. Am J Kidney Dis 38:S172-S174

31. Reichel H, Esser A, Roth HJ, Schmidt-Gayk H (2003) Influence of PTH assay methodology on differential diagnosis of renal bone disease. Nephrol Dial Transplant 18:759-768

32. Salusky IB, Goodman WG, Kuizon BD, Lavigne JR, Zahranik RJ, Gales B, Wang HJ, Elashoff RM, Juppner H (2003) Similar predictive value of bone turnover using first- and secondgeneration immunometric PTH assays in pediatric patients treated with peritoneal dialysis. Kidney Int 63:1801-1808 